\title{
Template Synthesis of Symmetrical Transition Metal Dithiocarbamates
}

\author{
Khwaja S. Siddiqi, ${ }^{*, a}$ Shahab A. A. Nami, ${ }^{a}$ Lutfullah $^{a}$ and Yonas Chebude ${ }^{b}$ \\ ${ }^{a}$ Department of Chemistry, Aligarh Muslim University, Aligarh-202002, India \\ ${ }^{b}$ Department of Chemistry, Addis Ababa University, Addis Ababa-1176, Ethiopia
}

\begin{abstract}
Novos ditiocarbamatos de metais de transição do tipo $\left[\mathrm{M}_{2}(\text { etdtc })_{2}\right]$ e $\left[\mathrm{M}^{1}(\mathrm{etdtc}) \mathrm{Cl}\right]_{2}[\mathrm{M}=\mathrm{Mn}(\mathrm{II})$, $\mathrm{Fe}(\mathrm{II}), \mathrm{Co}(\mathrm{II}), \mathrm{Ni}(\mathrm{II}), \mathrm{Cu}(\mathrm{II}), \mathrm{Zn}$ (II), $\mathrm{Cd}$ (II) e $\mathrm{Hg}$ (II), $\mathrm{M}^{1}=\mathrm{Cr}(\mathrm{III}), \mathrm{Fe}(\mathrm{III})$ e etdtc $\left.=\left(\mathrm{S}_{4} \mathrm{~N}_{4} \mathrm{C}_{11} \mathrm{H}_{18}\right)\right]$ foram sintetizados por meio de técnicas de automontagem. Os ditiocarbamatos metálicos foram preparados a partir da amina primária, $\mathrm{CS}_{2}$ e cloreto metálico. Foram caracterizados por técnicas espectroscópicas, TGA/DSC, susceptibilidade magnética e dados de condutividade. Sugere-se que os complexos $\left[\mathrm{Mn}_{2}(\text { etdtc })_{2}\right],\left[\mathrm{Fe}_{2}(\text { etdtc })_{2}\right],\left[\mathrm{Co}_{2}(\text { etdtc })_{2}\right],\left[\mathrm{Zn}_{2}(\text { etdtc })_{2}\right],\left[\mathrm{Cd}_{2}(\text { etdtc })_{2}\right]$ e $\left[\mathrm{Hg}_{2}(\text { etdtc })_{2}\right]$ tenham geometria tetraédrica, e $\left[\mathrm{Ni}_{2}(\mathrm{etdtc})_{2}\right]$ e $\left[\mathrm{Cu}_{2}(\mathrm{etdtc})_{2}\right]$, quadrática plana. Os complexos $[\mathrm{Cr}(\mathrm{etdtc}) \mathrm{Cl}]_{2}$ e $[\mathrm{Fe}(\text { etdtc }) \mathrm{Cl}]_{2}$ contêm ligantes cloro em ponte e possuem geometria octaédrica distorcida. Em todos os casos, o ligante ditiocarbamato encontra-se ligado simetricamente. No perfil da curva TG são observados três estágios para todos os complexos, levando à formação dos respectivos sulfetos metálicos como produtos finais. A condutância molar de soluções dos complexos em DMSO de concentração $10^{-3} \mathrm{~mol} \mathrm{~L}^{-1}$ confirma sua natureza não iônica.
\end{abstract}

Novel transition metal dithiocarbamates of the type $\left[\mathrm{M}_{2}(\text { etdtc })_{2}\right]$ and $\left[\mathrm{M}^{1}(\text { etdtc }) \mathrm{Cl}\right]_{2}$ where $\mathrm{M}=$ $\mathrm{Mn}(\mathrm{II}), \mathrm{Fe}(\mathrm{II}), \mathrm{Co}(\mathrm{II}), \mathrm{Ni}(\mathrm{II}), \mathrm{Cu}(\mathrm{II}), \mathrm{Zn}(\mathrm{II}), \mathrm{Cd}(\mathrm{II})$ and $\mathrm{Hg}(\mathrm{II}), \mathrm{M}^{1}=\mathrm{Cr}(\mathrm{III}), \mathrm{Fe}(\mathrm{III})$ and etdtc = $\left(\mathrm{S}_{4} \mathrm{~N}_{4} \mathrm{C}_{11} \mathrm{H}_{18}\right)$ have been synthesized by the use of self-assembly techniques. The metal dithiocarbamates were prepared from the primary amine, $\mathrm{CS}_{2}$ and metal chloride. They have been characterized by spectroscopic, TGA/DSC, magnetic susceptibility and conductivity data. The complexes, $\left[\mathrm{Mn}_{2}(\mathrm{etdtc})_{2}\right],\left[\mathrm{Fe}_{2}(\mathrm{etdtc})_{2}\right],\left[\mathrm{Co}_{2}(\mathrm{etdtc})_{2}\right],\left[\mathrm{Zn}_{2}(\mathrm{etdtc})_{2}\right],\left[\mathrm{Cd}_{2}(\mathrm{etdtc})_{2}\right]$ and $\left[\mathrm{Hg}_{2}(\mathrm{etdtc})_{2}\right]$ have been suggested to be tetrahedral while $\left[\mathrm{Ni}_{2}(\text { etdtc })_{2}\right]$ and $\left[\mathrm{Cu}_{2}(\mathrm{etdtc})_{2}\right]$ have square-planar geometry. $[\mathrm{Cr}(\mathrm{etdtc}) \mathrm{Cl}]_{2}$ and $[\mathrm{Fe}(\mathrm{etdtc}) \mathrm{Cl}]_{2}$ have chlorine bridged distorted-octahedral geometry. It has been observed that the dithiocarbamato moiety is symmetrically bonded in all the cases. A three stage TGA profile is observed for all the complexes leading to the formation of respective metal sulfide as the end-product. The molar conductance of $10^{-3} \mathrm{~mol} \mathrm{~L}^{-1}$ solution of the complexes measured in DMSO is indicative of their non-ionic nature.

Keywords: dithiocarbamates, transition metals, thermal analysis, symmetrical bonding

\section{Introduction}

Dithiocarbamates are used to stabilize a wide range of oxidation states of different metal ions. ${ }^{1}$ A large number of compounds are known where $\mathrm{CS}_{2}$ binds in $\eta^{1}$-end on, $\eta^{2}$ side or in $\eta^{3}$-coordination modes. ${ }^{2-4}$ The major advantage of using the small bite-angle of dithiocarbamato moiety as a stabilizing chelating ligand, is its unique property to remain intact under a variety of reaction conditions. ${ }^{5}$

Nowadays copper(II) dithiocarbamate is successfully used as single source precursor for the growth of semiconducting copper sulfide thin films. ${ }^{6}$ The iron(II), iron(III) dithiocarbamates have been studied for their spin-

* e-mail: khwajas_siddiqi@yahoo.co.in crossover phenomenon, ${ }^{7}$ radical traps for $\mathrm{NO},{ }^{8}$ and as antioxidants and pro-oxidants in biological systems. ${ }^{9}$ Diethyl dithiocarbamates are also known to inhibit the activity of $\mathrm{Cu} / \mathrm{Zn}$-superoxidedismutase (SOD) through the withdrawal of copper from the protein both in vivo and in vitro. ${ }^{10}$ Some dialkyl-substituted dithiocarbamates have proved to be an efficient anti-alkylating, anti-HIV and froth-floatation agents. ${ }^{11}$ The optical and electrochemical properties of dithiocarbamates can effectively be used to construct sensors for guest molecules and macromolecules. ${ }^{12-14}$

In this paper, we report a convenient one-pot synthesis of the transition metal dithiocarbamates via template procedure. In the present work, a condensation reaction was carried out between acetylacetone, ethylenediamine, 
carbon disulfide in a single step leading to the formation of a ring like complex (Figure 1 and Figure 2).

\section{Experimental}

Hydrated metal chlorides (BDH) acetylacetone, carbon disulfide (Merck) and ethylenediamine (Ranbaxy) were used as received. Methanol was used after distillation. Elemental analyses (C, H, N and S) were carried out with a Flash EA1112 Analyser, CE Instrument. IR spectra (4000-400 $\left.\mathrm{cm}^{-1}\right)$ were recorded on a FT-IR Perkin-Elmer Spectrum BX as KBr disc while the $600-200 \mathrm{~cm}^{-1}$ range were scanned on CsI on Nexus FT-IR Thermo Nicolet, Madison Wisconsin. The conductivity measurements were carried out with a CM82T Elico conductivity bridge in DMSO. The electronic spectra were recorded on a Cintra 5GBC spectrophotometer in DMSO. Magnetic susceptibility measurements were done with a Sherwood Scientific MSB Auto at room temperature. TGA/DSC was performed with a Universal V3.8 B TA SDT Q600 Build 51 Thermal Analyzer under nitrogen atmosphere using alumina powder as reference material. The heating rate was maintained at $10{ }^{\circ} \mathrm{C} \mathrm{min}^{-1}$. The metal contents were estimated by complexometric titrations, ${ }^{15}$ while the chlorine<smiles>CC(=O)CC(C)=O</smiles><smiles>CC(C)C(C)C</smiles>

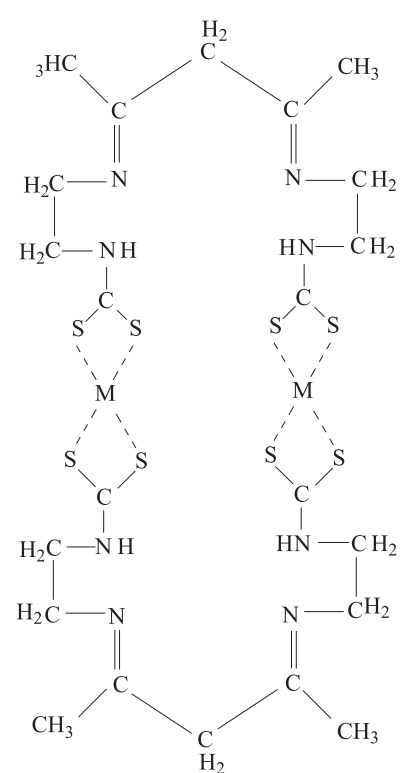

Figure 1. Proposed structure of $\left[\mathrm{M}_{2}(\mathrm{etdtc})_{2}\right]$ where $\mathrm{M}=\mathrm{Mn}(\mathrm{II})$, $\mathrm{Fe}(\mathrm{II}), \mathrm{Co}(\mathrm{II}), \mathrm{Ni}(\mathrm{II}), \mathrm{Cu}(\mathrm{II}), \mathrm{Zn}(\mathrm{II}), \mathrm{Cd}(\mathrm{II}), \mathrm{Hg}(\mathrm{II})$ and etdtc $=$ $\left(\mathrm{S}_{4} \mathrm{~N}_{4} \mathrm{C}_{11} \mathrm{H}_{18}\right)$. was determined gravimetrically as $\mathrm{AgCl}$ in case of $\mathrm{Cr}(\mathrm{III})$ and $\mathrm{Fe}(\mathrm{III})$ complexes. ${ }^{16}$

\section{Synthesis of the complexes}

In $40 \mathrm{~mL}$ methanolic solution of acetylacetone (20.0 mmol, $2.05 \mathrm{~mL}$ ) neat ethylenediamine $(40.0 \mathrm{mmol}, 2.67$ $\mathrm{mL}$ ), carbon disulfide ( $40.0 \mathrm{mmol}, 2.41 \mathrm{~mL})$ and hydrated metal chloride $(20.0 \mathrm{mmol})$ dissolved in $20 \mathrm{~mL}$ methanol were added simultaneously in a single pot to obtain a brisk precipitation of the metal dithiocarbamate in moderate yields. The precipitate was filtered, thoroughly washed with methanol and dried over calcium chloride in vacuo.

\section{Results and Discussion}

The microanalytical data (Table 1) correspond to the composition $\left[\mathrm{M}_{2}(\mathrm{etdtc})_{2}\right]$ and $\left[\mathrm{M}^{1}(\text { etdtc }) \mathrm{Cl}\right]_{2}$ where $\mathrm{M}=$ $\mathrm{Mn}$ (II), $\mathrm{Fe}$ (II), $\mathrm{Co}$ (II), $\mathrm{Ni}$ (II), $\mathrm{Cu}$ (II), $\mathrm{Zn}$ (II), $\mathrm{Cd}$ (II) and $\mathrm{Hg}$ (II), $\mathrm{M}^{1}=\mathrm{Cr}(\mathrm{III}), \mathrm{Fe}(\mathrm{III})$ and etdtc $=\left(\mathrm{S}_{4} \mathrm{~N}_{4} \mathrm{C}_{11} \mathrm{H}_{18}\right)$ as shown in Figures 1 and 2. The complexes are stable to moisture and heat. The complexes are amorphous powder, soluble in DMSO only. The molar conductance of $10^{-3} \mathrm{~mol} \mathrm{~L}^{-1}$<smiles>CC(=O)CC(=O)C(Cl)Cl</smiles><smiles>CC1=NCCNC2NCCNC(S1)S2</smiles>

Figure 2. Proposed structure of $\left[\mathrm{M}^{1}(\text { etdtc }) C l\right]_{2}$, where $\mathrm{M}^{1}=\mathrm{Cr}(\mathrm{III})$ and $\mathrm{Fe}(\mathrm{III})$ and etdtc $=\left(\mathrm{S}_{4} \mathrm{~N}_{4} \mathrm{C}_{11} \mathrm{H}_{18}\right)$. 
solutions of the complexes in DMSO are indicative of their non-electrolytic nature. ${ }^{17}$

\section{IR spectra}

In metal dithiocarbamato complexes the region 950$1050 \mathrm{~cm}^{-1}$ is considered characteristic of the nature of binding of the dithiocarbamato moiety. According to the criterion of Bonati and Ugo, ${ }^{18}$ the presence of a solitary band in the above region is due to symmetrical bidentate coordination of the dithiocarbamato group while the splitting of this band within a narrow range of $20 \mathrm{~cm}^{-1}$ is due to the unsymmetrical monodentate nature of the dithiocarbamato group shown below:

Bidentate symmetrical bonding

In the present study, a single sharp band of high intensity has been observed in all the complexes in 1017$1036 \mathrm{~cm}^{-1}$ range, suggesting symmetrical bidentate binding of the dithiocarbamato moiety. ${ }^{19}$ It has been shown from the crystal and molecular structure of $\left[\mathrm{NiCl}(\mathrm{tzdtc})\left(\mathrm{PPh}_{3}\right)\right] 0.5 \mathrm{CHCl}_{3}$ that the $\mathrm{C}-\mathrm{N}$ and $\mathrm{C}-\mathrm{S}$ bond distances are shorter than the corresponding $\mathrm{C}-\mathrm{N}$ and $\mathrm{C}-\mathrm{S}$ distances in pyridine and thiophene, respectively which is due to the delocalization of electrons, ${ }^{20}$ over the entire $\mathrm{NCS}_{2}$ group after chelation:<smiles>[NH3+]C([15NH])=S</smiles><smiles>[N+]=C1SN=[SH]1</smiles>

Consequently the C-N and C-S stretching frequencies of the thioureide band also changes (Table 2) showing partial double bond character of $\mathrm{S}_{2} \mathrm{CN}$. It has been shown from a study of alkyl dithiocarbamates that the lengthening of the alkyl chain is accompanied by a decrease in $v(\mathrm{C}-\mathrm{N})$ although the $v(\mathrm{C}-\mathrm{S})$ remains unaltered as it has been found to be insensitive to the nature of alkyl substituents. ${ }^{21}$

The $v(\mathrm{M}-\mathrm{S}),{ }^{22}$ occurring in the far-IR region depends on the nature of the metal ion and the substituents attached with the sulfur. We have observed medium intensity $v(\mathrm{M}-\mathrm{S})$ in the $527-442 \mathrm{~cm}^{-1}$ range which is in agreement with the observations made by Sonbati. ${ }^{23}$

On the basis of normal coordinate analysis of nonplanar halogen bridged molecules it has been found that the bridging $v(\mathrm{M}-\mathrm{X})$ are $40-45 \%$ lower than the terminal $v(\mathrm{M}-\mathrm{X}){ }^{24-26}$ The four absorption bands found for terminal $\mathrm{M}-\mathrm{X}$ bonds have higher frequencies while the bridging $\mathrm{M}-\mathrm{Cl}$ are relatively weaker and appear in lower wave number region. In the case of $[\mathrm{Fe}(\text { etdtc }) \mathrm{Cl}]_{2}$ complex, two medium and two strong $v(\mathrm{M}-\mathrm{X})$ have been observed in $248-331 \mathrm{~cm}^{-1}$ region which is probably due to the bridging $\mathrm{M}-\mathrm{Cl}$ group. The magnetic moment value is not very conclusive (3.67 B.M.) but it may be due to an equilibrium between high-spin and low-spin $\mathrm{Fe}(\mathrm{III}) .{ }^{27}$ Moreover, a halogen bridged structure of this compound would be more stable with respect to non-halogen bridged five coordinate $\mathrm{Fe}(\mathrm{III})$.

Table 1. Analytical data and molar conductance of the complexes

\begin{tabular}{|c|c|c|c|c|c|c|c|c|c|}
\hline \multirow[t]{2}{*}{$\begin{array}{l}\text { Compounds } \\
\text { (Formula Weight) }\end{array}$} & \multirow[t]{2}{*}{ Colour } & \multirow[t]{2}{*}{$\begin{array}{l}\mathrm{mp} \\
\left({ }^{\circ} \mathrm{C}\right)\end{array}$} & \multirow[t]{2}{*}{$\begin{array}{c}\text { Yield } \\
(\%)\end{array}$} & \multirow{2}{*}{$\begin{array}{c}\text { Molar } \\
\text { Conductance } \\
\left(\mathrm{ohm}^{-1} \mathrm{~mol}^{-1} \mathrm{~cm}^{2}\right)\end{array}$} & \multicolumn{5}{|c|}{$\begin{array}{l}\text { Found (Calc.) Analysis } \\
\qquad(\%)\end{array}$} \\
\hline & & & & & $\mathrm{C}$ & $\mathrm{H}$ & $\mathrm{N}$ & $S$ & M \\
\hline $\begin{array}{l}{\left[\mathrm{Mn}_{2}(\mathrm{etdtc})_{2}\right]} \\
(778.94)\end{array}$ & Light brown & 109 & 55 & 13.1 & $\begin{array}{c}33.87 \\
(33.95)\end{array}$ & $\begin{array}{c}4.79 \\
(4.65)\end{array}$ & $\begin{array}{c}14.13 \\
(14.38)\end{array}$ & $\begin{array}{c}32.76 \\
(32.93)\end{array}$ & $\begin{array}{c}14.34 \\
(14.10)\end{array}$ \\
\hline $\begin{array}{l}{\left[\mathrm{Fe}_{2}(\text { etdtc })_{2}\right]} \\
(780.76)\end{array}$ & Dark brown & 144 & 62 & 32.5 & $\begin{array}{c}34.06 \\
(33.84)\end{array}$ & $\begin{array}{c}4.32 \\
(4.64)\end{array}$ & $\begin{array}{c}14.09 \\
(14.35)\end{array}$ & $\begin{array}{c}32.66 \\
(32.85)\end{array}$ & $\begin{array}{l}14.59 \\
(14.3)\end{array}$ \\
\hline $\begin{array}{l}{\left[\mathrm{Co}_{2}(\mathrm{etdtc})_{2}\right]} \\
(786.93)\end{array}$ & Green & 191 & 67 & 17.2 & $\begin{array}{c}33.87 \\
(33.57)\end{array}$ & $\begin{array}{c}4.78 \\
(4.61)\end{array}$ & $\begin{array}{c}14.02 \\
(14.23)\end{array}$ & $\begin{array}{c}32.45 \\
(32.59)\end{array}$ & $\begin{array}{c}15.09 \\
(14.97)\end{array}$ \\
\hline $\begin{array}{l}{\left[\mathrm{Ni}_{2}(\text { etdtc })_{2}\right]} \\
(786.48)\end{array}$ & Algae green & 183 & 70 & 31.7 & $\begin{array}{l}33.78 \\
(33.57)\end{array}$ & $\begin{array}{c}4.87 \\
(4.61)\end{array}$ & $\begin{array}{l}14.08 \\
(14.23)\end{array}$ & $\begin{array}{c}32.54 \\
(32.59)\end{array}$ & $\begin{array}{c}14.85 \\
(14.92)\end{array}$ \\
\hline $\begin{array}{l}{\left[\mathrm{Cu}_{2}(\mathrm{etdtc})_{2}\right]} \\
(796.15)\end{array}$ & Yellow & 103 & 68 & 10.8 & $\begin{array}{c}33.29 \\
(33.18)\end{array}$ & $\begin{array}{c}4.72 \\
(4.55)\end{array}$ & $\begin{array}{l}13.98 \\
(14.07)\end{array}$ & $\begin{array}{c}32.04 \\
(32.21)\end{array}$ & $\begin{array}{l}15.88 \\
(15.96)\end{array}$ \\
\hline $\begin{array}{l}{\left[\mathrm{Zn}_{2}(\text { etdtc })_{2}\right]} \\
(799.82)\end{array}$ & Yellow & 171 & 55 & 8.7 & $\begin{array}{c}33.18 \\
(33.03)\end{array}$ & $\begin{array}{c}4.71 \\
(4.54)\end{array}$ & $\begin{array}{l}13.86 \\
(14.0)\end{array}$ & $\begin{array}{c}32.05 \\
(32.07)\end{array}$ & $\begin{array}{c}16.28 \\
(16.34)\end{array}$ \\
\hline $\begin{array}{l}{\left[\mathrm{Cd}_{2}(\text { etdtc })_{2}\right]} \\
(893.86)\end{array}$ & Dirty white & 118 & 48 & 9.2 & $\begin{array}{c}29.67 \\
(29.55)\end{array}$ & $\begin{array}{c}4.24 \\
(4.06)\end{array}$ & $\begin{array}{c}12.56 \\
(12.53)\end{array}$ & $\begin{array}{c}28.44 \\
(28.69)\end{array}$ & $\begin{array}{c}25.13 \\
(25.14)\end{array}$ \\
\hline $\begin{array}{l}{\left[\mathrm{Hg}_{2}(\text { etdtc })_{2}\right]} \\
(1070.24)\end{array}$ & Black & 149 & 72 & 14.7 & $\begin{array}{l}24.79 \\
(24.68)\end{array}$ & $\begin{array}{c}3.35 \\
(3.39)\end{array}$ & $\begin{array}{l}10.54 \\
(10.46)\end{array}$ & $\begin{array}{c}23.73 \\
(23.96)\end{array}$ & $\begin{array}{c}37.44 \\
(37.48)\end{array}$ \\
\hline $\begin{array}{l}{[\mathrm{Cr}(\text { etdtc }) \mathrm{Cl}]_{2}} \\
(843.96)\end{array}$ & Bluish-green & 160 & 70 & 21.6 & $\begin{array}{c}31.41 \\
(31.33)\end{array}$ & $\begin{array}{c}4.42 \\
(4.29)\end{array}$ & $\begin{array}{l}13.19 \\
(13.27)\end{array}$ & $\begin{array}{c}33.23 \\
(30.39)\end{array}$ & $\begin{array}{c}12.21 \\
(12.32)\end{array}$ \\
\hline $\begin{array}{l}{[\mathrm{Fe}(\mathrm{etdtc}) \mathrm{Cl}]_{2}} \\
(851.664)\end{array}$ & Dark brown & 130 & 70 & 41.1 & $\begin{array}{l}31.23 \\
(31.02)\end{array}$ & $\begin{array}{c}4.41 \\
(4.26)\end{array}$ & $\begin{array}{l}13.09 \\
(13.15)\end{array}$ & $\begin{array}{c}29.96 \\
(30.11)\end{array}$ & $\begin{array}{c}13.23 \\
(13.11)\end{array}$ \\
\hline
\end{tabular}


For a triply bridged $\mathrm{Cr}_{2} \mathrm{Cl}_{9}^{3-}$ there are twelve infra red active bands above 200 wave number but only two terminal $v(\mathrm{Cr}-\mathrm{Cl})$ are observed. Terminal $\mathrm{Cr}-\mathrm{Cl}$ bonds are stronger than the bridging ones as has been observed in the case of Fe-complex. $\mathrm{In}_{2} \mathrm{Cr}_{2}{ }_{9}^{3-}$ there are two strong $\mathrm{Cr}-\mathrm{Cl}$ terminal bonds while the weaker ones have been ascribed to bridging $\mathrm{Cr}-\mathrm{Cl}$ bonds. ${ }^{28,29}$ However, we have observed two medium intensity bands in the case of $[\mathrm{Cr}(\text { etdtc }) \mathrm{Cl}]_{2}$ which are assigned to bridging $v(\mathrm{Cr}-\mathrm{Cl})$ (Table 2$)$.

\section{Electronic spectra and magnetic moments}

The octahedral $\mathrm{Cr}$ (III) ion is known to exhibit two prominent bands at 17,000 and $24,000 \mathrm{~cm}^{-1}$ besides a very weak charge transfer as a shoulder, approximately at 37,000 $\mathrm{cm}^{-1}$. The other weak absorptions are insignificant as they

Table 2. Important IR bands $\left(\mathrm{cm}^{-1}\right)$ and their assignments

\begin{tabular}{lccccc}
\hline Compounds & $v(\mathrm{M}-\mathrm{Cl})_{\mathrm{b}}$ & $v(\mathrm{M}-\mathrm{S})$ & $v(\mathrm{C}-\mathrm{S})$ & $v(\mathrm{C}=\mathrm{N})$ & $\begin{array}{c}\text { Thioureide } \\
\text { band }\end{array}$ \\
\hline$\left[\mathrm{Mn}_{2}(\text { etdtc })_{2}\right]$ & - & $508 \mathrm{~m}$ & $1017 \mathrm{~s}$ & $1601 \mathrm{~m}$ & $1520 \mathrm{~s}$ \\
{$\left[\mathrm{Fe}_{2}(\text { etdtc })_{2}\right]$} & - & $508 \mathrm{~m}$ & $1034 \mathrm{~s}$ & $1601 \mathrm{~m}$ & $1511 \mathrm{~s}$ \\
{$\left[\mathrm{Co}_{2}(\text { etdtc })_{2}\right]$} & - & $464 \mathrm{~m}$ & $1051 \mathrm{~s}$ & $1602 \mathrm{~m}$ & $1516 \mathrm{~s}$ \\
{$\left[\mathrm{Ni}_{2}(\text { etdtc })_{2}\right]$} & - & $442 \mathrm{~m}$ & $1036 \mathrm{~s}$ & $1601 \mathrm{~m}$ & $1540 \mathrm{~s}$ \\
$\left.\left[\mathrm{Cu}_{2} \text { (etdtc }\right)_{2}\right]$ & - & $461 \mathrm{~m}$ & $1039 \mathrm{~s}$ & $1601 \mathrm{~m}$ & $1532 \mathrm{~s}$ \\
{$\left[\mathrm{Zn}_{2}(\text { etdtc })_{2}\right]$} & - & $467 \mathrm{~m}$ & $1033 \mathrm{~s}$ & $1602 \mathrm{~m}$ & $1515 \mathrm{~s}$ \\
$\left.\left[\mathrm{Cd}_{2} \text { (etdtc }\right)_{2}\right]$ & - & $474 \mathrm{~m}$ & $1035 \mathrm{~s}$ & $1601 \mathrm{~m}$ & $1510 \mathrm{~s}$ \\
{$\left[\mathrm{Hg}_{2}(\text { etdtc })_{2}\right]$} & - & $488 \mathrm{~m}$ & $1034 \mathrm{~s}$ & $1601 \mathrm{~m}$ & $1513 \mathrm{~s}$ \\
{$[\mathrm{Cr}(\text { etdtc }) \mathrm{Cl}]_{2}$} & $256 \mathrm{~m}$ & $502 \mathrm{~m}$ & $1034 \mathrm{~s}$ & $1602 \mathrm{~m}$ & $1511 \mathrm{~s}$ \\
& $283 \mathrm{~m}$ & & & & \\
{$[\mathrm{Fe}(\text { etdtc }) \mathrm{Cl}]_{2}$} & $(278,296) \mathrm{m}$ & $527 \mathrm{~m}$ & $1034 \mathrm{~s}$ & $1601 \mathrm{~m}$ & $1522 \mathrm{~s}$ \\
& $(248,331) \mathrm{s}$ & & & & \\
\hline
\end{tabular}

are spin forbidden. We have observed three bands in the case of $[\mathrm{Cr}(\text { etdtc }) \mathrm{Cl}]_{2}$ and assigned to the transitions from ${ }^{4} \mathrm{~A}_{2 \mathrm{~g}}$ ground term to three excited quartet terms (Table 3). The magnetic moment of 3.74 B.M. calculated for three unpaired electrons and the $\mathrm{d}-\mathrm{d}$ bands are suggestive of an octahedral geometry for $\mathrm{Cr}(\mathrm{III})$ in the $[\mathrm{Cr} \text { (etdtc) } \mathrm{Cl}]_{2}$ complex. ${ }^{30}$ The Racah parameters calculated are indicative of considerable metal-ligand bond character.

A variety of $\mathrm{Fe}$ (III) dithiocarbamato complexes have been reported. In the case of trisdialkyl dithiocarbamate $\mathrm{Fe}(\mathrm{III})$ complexes a trigonally distorted octahedral structure has been shown. ${ }^{31}$ However, when one or two dithiocarbamate groups are substituted by other bidentate ligands the extent of distortion increases.

It has been shown by Hoskins and White, ${ }^{32}$ from the molecular and crystal structure of monochlorobisdiethyldithiocarbamate $\mathrm{Fe}$ (III) that it has a square-pyramidal structure. It is monomeric in solid state with a magnetic moment value of 3.9 B.M. In the present complex, [Fe(etdtc) Cl $]_{2}$, each Fe(III) atom is surrounded by four sulfur atoms and one free chlorine. The proximity of the chlorine may be a reason for chlorine bridged octahedral structure. A value of 3.67 B.M. has been found at room temperature for the complex, $[\mathrm{Fe}(\text { etdtc }) \mathrm{Cl}]_{2}$ which may be regarded as a population-weighted-average, ${ }^{27}$ due to the spin-cross between high ( $\mu_{\text {eff }}=5.9$ B.M.) and low$\operatorname{spin}\left(\mu_{\text {eff }}=1.88\right.$ B.M.). Three intense bands at 27,548; 24,509 and $19,032 \mathrm{~cm}^{-1}$ further supports the proposed octahedral geometry for $[\mathrm{Fe}(\text { etdtc }) \mathrm{Cl}]_{2}$ complex.

The characteristic colour of tetrahedral Mn(II) complexes is generally yellow or yellowish green as opposed to

Table 3. Magnetic moments and electronic spectra of the complexes

\begin{tabular}{|c|c|c|c|c|c|c|c|}
\hline Compounds & $\begin{array}{c}\text { Magnetic } \\
\text { moment (B.M.) }\end{array}$ & $\begin{array}{l}\text { Electronic } \\
\text { bands }\left(\mathrm{cm}^{-1}\right)\end{array}$ & $\begin{array}{c}\log \varepsilon \\
\left(\mathrm{L} \mathrm{mol}^{-1} \mathrm{~cm}^{-1}\right)\end{array}$ & Possible assignments & $\begin{array}{l}10 \mathrm{Dq} \\
\left(\mathrm{cm}^{-1}\right)\end{array}$ & $\begin{array}{c}\mathrm{B} \\
\left(\mathrm{cm}^{-1}\right)\end{array}$ & $\beta$ \\
\hline$[\mathrm{Cr}(\text { etdtc }) \mathrm{Cl}]_{2}$ & 3.74 & $\begin{array}{l}35,714 \\
26,881 \\
15,503\end{array}$ & $\begin{array}{l}3.58 \\
3.05 \\
2.55\end{array}$ & $\begin{array}{l}{ }^{4} \mathrm{~T}_{1 \mathrm{~g}}(\mathrm{P}) \longleftarrow{ }^{4} \mathrm{~A}_{2 \mathrm{~g}}(\mathrm{~F}) \\
{ }^{4} \mathrm{~T}_{1 \mathrm{~g}}(\mathrm{~F}) \longleftarrow{ }^{4} \mathrm{~A}_{2 \mathrm{~g}}(\mathrm{~F}) \\
{ }^{4} \mathrm{~T}_{2 \mathrm{~g}}(\mathrm{~F}) \longleftarrow{ }^{4} \mathrm{~A}_{2 \mathrm{~g}}(\mathrm{~F})\end{array}$ & 15,880 & 397 & 0.69 \\
\hline$[\mathrm{Fe}(\text { etdtc }) \mathrm{Cl}]_{2}$ & 3.67 & $\begin{array}{l}27,548 \\
24,509 \\
19,032\end{array}$ & $\begin{array}{l}3.36 \\
3.15 \\
2.48\end{array}$ & $\begin{array}{l}{ }^{4} \mathrm{~T}_{1 \mathrm{~g}}(\mathrm{D}) \longleftarrow{ }^{6} \mathrm{~A}_{1 \mathrm{~g}} \\
{ }^{4} \mathrm{~T}_{2 \mathrm{~g}}(\mathrm{G}) \longleftarrow{ }^{6} \mathrm{~A}_{1 \mathrm{~g}} \\
{ }^{4} \mathrm{~T}_{1 \mathrm{~g}}(\mathrm{G}) \longleftarrow{ }^{6} \mathrm{~A}_{1 \mathrm{~g}}\end{array}$ & 19,750 & 412 & 0.89 \\
\hline$\left[\mathrm{Mn}_{2}(\text { etdtc })_{2}\right]$ & 5.72 & $\begin{array}{l}32,051 \\
30,674 \\
24,630\end{array}$ & $\begin{array}{l}3.57 \\
3.39 \\
1.68\end{array}$ & $\begin{array}{l}\text { Charge transfer } \\
\text { Charge transfer } \\
{ }^{4} \mathrm{~T}_{1} \longleftarrow{ }^{6} \mathrm{~A}_{1}\end{array}$ & - & - & - \\
\hline$\left[\mathrm{Fe}_{2}(\text { etdtc })_{2}\right]$ & 5.05 & $\begin{array}{l}31,250 \\
25,906 \\
21,052\end{array}$ & $\begin{array}{l}3.58 \\
3.10 \\
2.81\end{array}$ & $\begin{array}{l}\text { Charge transfer } \\
\text { Charge transfer } \\
{ }^{5} \mathrm{E} \longleftarrow{ }^{5} \mathrm{~T}_{2}\end{array}$ & - & - & - \\
\hline$\left[\mathrm{Co}_{2}(\text { etdtc })_{2}\right]$ & 4.38 & $\begin{array}{l}27,100 \\
22,471 \\
15,600\end{array}$ & $\begin{array}{l}3.55 \\
3.31 \\
2.89\end{array}$ & 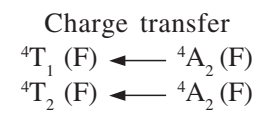 & 15,720 & 463 & 0.90 \\
\hline$\left[\mathrm{Ni}_{2}(\mathrm{etdtc})_{2}\right]$ & Diamagnetic & $\begin{array}{l}23,696 \\
15,503\end{array}$ & $\begin{array}{l}3.22 \\
2.08\end{array}$ & $\begin{array}{l}{ }^{1} \mathrm{~B}_{1 \mathrm{~g}} \longleftarrow{ }^{1} \mathrm{~A}_{1 \mathrm{~g}} \\
{ }^{1} \mathrm{~A}_{2 \mathrm{~g}} \longleftarrow{ }^{1} \mathrm{~A}_{1 \mathrm{~g}}\end{array}$ & 15,560 & - & - \\
\hline$\left[\mathrm{Cu}_{2}(\text { etdtc })_{2}\right]$ & 1.83 & $\begin{array}{l}24,570 \\
18,384 \\
13,330\end{array}$ & $\begin{array}{l}3.15 \\
2.45 \\
1.78\end{array}$ & $\begin{array}{l}\text { Charge transfer } \\
{ }^{2} \mathrm{~A}_{1 \mathrm{~g}} \longleftarrow{ }^{2} \mathrm{~B}_{1 \mathrm{~g}} \\
{ }^{2} \mathrm{E}_{\mathrm{g}} \longleftarrow{ }^{2} \mathrm{~B}_{1 \mathrm{~g}}\end{array}$ & - & - & - \\
\hline
\end{tabular}


octahedral $\mathrm{Mn}(\mathrm{II})$ complexes. $\left[\mathrm{Mn}_{2}(\text { etdtc })_{2}\right.$ ] exhibits yellowish green colour in that absorbs in the visible region at $24,630 \mathrm{~cm}^{-1}$ assigned to ${ }^{4} \mathrm{~T}_{1} \leftarrow{ }^{6} \mathrm{~A}_{1}$ transition. In addition, it also shows two charge transfer bands at 32,051 and 30,674 $\mathrm{cm}^{-1}$. The magnetic moment of $\mathrm{Mn}(\mathrm{II})$ in $\left[\mathrm{Mn}_{2}(\mathrm{etdtc})_{2}\right]$ complex (5.72 B.M.) is close to the calculated spin only value indicating a tetrahedral arrangement of $\mathrm{Mn}$ (II) ion. ${ }^{33}$

The tetrahedral high-spin Fe(II) complex shows one spin allowed d-d transition in the visible region at 21052 $\mathrm{cm}^{-1}$ corresponding to ${ }^{5} \mathrm{E} \leftarrow{ }^{5} \mathrm{~T}_{2}$ transition. The magnetic moment of tetrahedral $\mathrm{Fe}$ (II) complexes lies between 5.05.5 B.M. corresponding to four unpaired electrons while we have obtained a value of 5.05 B.M. which is consistent with the tetrahedral nature, ${ }^{34}$ of $\mathrm{Fe}(\mathrm{II})$ ion in $\left[\mathrm{Fe}_{2}(\mathrm{etdtc})_{2}\right]$.

For the tetrahedral $\mathrm{Co}$ (II) complexes two bands are observed at 15,600 and 22,471 $\mathrm{cm}^{-1}$ corresponding to ${ }^{4} \mathrm{~T}_{2}(\mathrm{~F})$ $\leftarrow{ }^{4} \mathrm{~A}_{2}(\mathrm{~F})$ and ${ }^{4} \mathrm{~T}_{1}(\mathrm{~F}) \leftarrow{ }^{4} \mathrm{~A}_{2}(\mathrm{~F})$ transitions, respectively, in addition to a charge transfer at $27,000 \mathrm{~cm}^{-1}$. The magnetic moment of tetrahedral, ${ }^{35} \mathrm{Co}$ (II) complexes lies in the range 4.2 to 4.7 B.M. while for octahedral Co(II) complexes it falls between 4.4 to 5.5 B.M. The observed value in the present case is 4.38 B.M. The ligand field spectrum and magnetic moment value suggest a tetrahedral environment around $\mathrm{Co}(\mathrm{II})$ ion.

An important feature of $\mathrm{Ni}-\mathrm{S}_{4}$ systems is the presence of high intensity absorption bands, which is also the case in present investigation. Two d-d transitions are observed at 15,503 and $23,696 \mathrm{~cm}^{-1}$ corresponding to the ${ }^{1} \mathrm{~A}_{2 \mathrm{~g}} \leftarrow$ ${ }^{1} \mathrm{~A}_{1 \mathrm{~g}}$ and ${ }^{1} \mathrm{~B}_{1 \mathrm{~g}} \leftarrow{ }^{1} \mathrm{~A}_{1 \mathrm{~g}}$ transitions, respectively which support a square-planar structure for the Ni(II) complex. ${ }^{36}$

The green $\mathrm{Cu}$ (II) complex shows two $\mathrm{d}$-d absorption bands at 18,384 and $13,330 \mathrm{~cm}^{-1}$ corresponding to ${ }^{2} \mathrm{~A}_{1 \mathrm{~g}} \leftarrow{ }^{2} \mathrm{~B}_{1 \mathrm{~g}}$ and
${ }^{2} \mathrm{E}_{\mathrm{g}} \leftarrow{ }^{2} \mathrm{~B}_{1 \mathrm{~g}}$ transitions, respectively and a charge transfer band at $24,570 \mathrm{~cm}^{-1}$. It is well known that for square-planar $\mathrm{Cu}$ (II) complexes the magnetic moment value falls in 1.82-1.86 B.M. while for tetrahedral $\mathrm{Cu}$ (II) ion, the $\mu_{\text {eff }}$ value is slightly higher (1.92-2.00 B.M.). ${ }^{37} \mathrm{~A}$ value of 1.83 B.M. for $\mathrm{Cu}$ (II) ion has been observed which is well within the expected region found for square-planar $\mathrm{Cu}$ (II) complexes.

\section{$T G A / D S C$}

The observed percentage weight loss corresponding to various steps in all the thermograms were compared (Table 4) with those calculated on the basis of possible decompositions of the expelled groups. ${ }^{38}$ Generally the dithiocarbamato complexes on pyrolysis either volatilize leaving behind negligible amount of residue or decompose to yield respective metal sulfide. ${ }^{39}$ In the present study the TGA profile consists of three well defined stages. The first stage starts above $100^{\circ} \mathrm{C}$ implying that that there is neither water nor solvent molecule attached to the complex. The first degradation step starts at $145{ }^{\circ} \mathrm{C}$ and nearly $9 \%$ of weight loss is observed corresponding to two methyl groups as methane (Calc. 8.2\%) and it continues upto a temperature range of $190{ }^{\circ} \mathrm{C}$. The second stage of decomposition starts from $200{ }^{\circ} \mathrm{C}$ and continues upto $550{ }^{\circ} \mathrm{C}$ involving decomposition of remaining organic moiety which constitutes approximately $65 \%$ (Calc. $64.2 \%$ ) of mass of the complex leaving behind the respective metal sulfide. ${ }^{40}$ Finally, the thermogram showed a straight line which did not change even on heating upto $700{ }^{\circ} \mathrm{C}$ indicating that there is no further change. Hence, respective metal sulfide is the end product of all the complexes.

Table 4. Degradation of various fragments in the complexes $\left[\mathrm{M}_{2}(\mathrm{edtc})_{2}\right]$

\begin{tabular}{|c|c|c|c|c|c|c|c|c|c|}
\hline \multirow[t]{2}{*}{ Complexes } & \multicolumn{3}{|c|}{ First decomposition stage } & \multicolumn{3}{|c|}{ Second decomposition stage } & \multicolumn{3}{|c|}{ Final Product Metal Residue } \\
\hline & Fragments & $\begin{array}{l}\text { Temp. } \\
\text { Range } \\
\left({ }^{\circ} \mathrm{C}\right)\end{array}$ & $\begin{array}{c}\text { Mass loss } \\
\text { data } \% \\
\text { Found (Calc.) }\end{array}$ & Fragments & $\begin{array}{l}\text { Temp. } \\
\text { Range } \\
\left({ }^{\circ} \mathrm{C}\right)\end{array}$ & $\begin{array}{c}\text { Mass loss } \\
\text { data \% } \\
\text { Found (Calc.) }\end{array}$ & Fragments & $\begin{array}{l}\text { Temp. } \\
\text { Range } \\
\left({ }^{\circ} \mathrm{C}\right)\end{array}$ & $\begin{array}{c}\text { Mass loss } \\
\text { data } \% \\
\text { Found (Calc.) }\end{array}$ \\
\hline$\left[\mathrm{Mn}_{2}(\mathrm{etdtc})_{2}\right]$ & $\begin{array}{l}\text { Two } \\
\text { methyl } \\
\text { groups }\end{array}$ & $142-190$ & $\begin{array}{c}8.58 \\
(8.24)\end{array}$ & $\begin{array}{l}\text { Whole } \\
\text { organic } \\
\text { moiety }\end{array}$ & $200-550$ & $\begin{array}{c}69.15 \\
(69.37)\end{array}$ & $2 \mathrm{MnS}$ & $550-700$ & $\begin{array}{c}21.88 \\
(22.36)\end{array}$ \\
\hline$\left[\mathrm{Fe}_{2}(\text { etdtc })_{2}\right]$ & - do- & $145-190$ & $\begin{array}{c}8.51 \\
(8.22)\end{array}$ & - do- & $200-550$ & $\begin{array}{c}64.89 \\
(65.09)\end{array}$ & $\mathrm{Fe}_{2} \mathrm{~S}_{3}$ & $550-700$ & $\begin{array}{c}26.29 \\
(26.62)\end{array}$ \\
\hline$\left[\mathrm{Co}_{2}(\mathrm{etdtc})_{2}\right]$ & - do- & $145-192$ & $\begin{array}{c}8.38 \\
(8.15)\end{array}$ & -do- & $200-550$ & $\begin{array}{c}68.41 \\
(68.68)\end{array}$ & $2 \mathrm{CoS}$ & $550-700$ & $\begin{array}{c}23.06 \\
(23.12)\end{array}$ \\
\hline$\left[\mathrm{Ni}_{2}(\text { etdtc })_{2}\right]$ & - do- & $150-192$ & $\begin{array}{c}8.04 \\
(8.16)\end{array}$ & - do- & $200-550$ & $\begin{array}{c}68.28 \\
(68.70)\end{array}$ & $2 \mathrm{NiS}$ & $550-700$ & $\begin{array}{c}23.27 \\
(23.08)\end{array}$ \\
\hline$\left[\mathrm{Cu}_{2}(\mathrm{etdtc})_{2}\right]$ & -do- & $147-194$ & $\begin{array}{c}7.82 \\
(8.06)\end{array}$ & -do- & $200-550$ & $\begin{array}{c}67.68 \\
(67.85)\end{array}$ & $2 \mathrm{CuS}$ & $550-700$ & $\begin{array}{c}24.27 \\
(24.03)\end{array}$ \\
\hline$\left[\mathrm{Zn}_{2}(\mathrm{etdtc})_{2}\right]$ & - do- & $145-190$ & $\begin{array}{c}8.23 \\
(8.02)\end{array}$ & - do- & $200-550$ & $\begin{array}{c}59.38 \\
(59.54)\end{array}$ & $2 \mathrm{ZnS}$ & $550-700$ & $\begin{array}{c}24.59 \\
(24.36)\end{array}$ \\
\hline$\left[\mathrm{Cd}_{2}(\mathrm{etdtc})_{2}\right]$ & - do- & $147-194$ & $\begin{array}{c}7.49 \\
(7.18)\end{array}$ & - do- & $200-550$ & $\begin{array}{c}60.08 \\
(60.38)\end{array}$ & $2 \mathrm{CdS}$ & $550-700$ & $\begin{array}{c}32.59 \\
(32.32)\end{array}$ \\
\hline$\left[\mathrm{Hg}_{2}(\text { etdtc })_{2}\right]$ & - do- & 145-189 & $\begin{array}{c}6.21 \\
(5.99)\end{array}$ & - do- & $200-550$ & $\begin{array}{c}50.21 \\
(50.56)\end{array}$ & $2 \mathrm{HgS}$ & $550-700$ & $\begin{array}{c}43.68 \\
(43.47)\end{array}$ \\
\hline
\end{tabular}


The DSC profile exhibits enthalpic changes from endothermal and exothermal bands and peaks. In the present case the DSC peaks correlate well with the TGA data. A sharp endothermic peak is observed in the temperature range of $150-200{ }^{\circ} \mathrm{C}$ due to the liberation of methane while a broad exothermic peak is obtained in between $300-400{ }^{\circ} \mathrm{C}$ due to the pyrolysis of the whole organic moiety. However, there is no well defined exotherm or endotherm corresponding to the last process of formation of metal sulfide.

\section{Conclusions}

The above work describes a convenient high yield template synthesis of ring type dithiocarbamates which can act as models to study the magnetic interaction between metal ions, and also mimic naturally occurring macrocyclic ligands. Furthermore, they can successfully be used as models for protein-metal binding sites in biological systems

\section{Acknowledgments}

One of the authors (SAAN) thanks the CSIR, New Delhi for financial assistance through grant No. 01(1783)/02/ EMR-II. Finally, authors thank the referees and the editor for their constructive comments.

\section{References}

1. Bond, A.M.; Martin, R.L.; Coord. Chem. Rev. 1984, 54, 23.

2. Kana, A.T.; Hibbert, T.G.; Mahon, M.F.; Molly, K.C.; Parkin, I.P.; Price, L.S.; Polyhedron 2001, 20, 2989.

3. Ivanov, A.V.; Antzukin, O.N.; Polyhedron 2002, 21, 2727.

4. Mathur, P.; Ghosh, A.K.; Mukhopadhyay, S.; Srinivasu, C.; Mobin, S.M.; J. Organomet. Chem. 2003, 678, 142.

5. Coffey, T.A.; Foster, G.D.; Hogarth, G.; J. Chem. Soc., Dalton Trans. 1996, 183.

6. Ngo, S.C.; Banger, K.K.; DelaRosa, M.J.; Toscano, P.J.; Welch, J.T.; Polyhedron 2003, 22, 1575.

7. Nigam, H.L.; Pandey, K.B.; Singh, R.; J. Indian Chem. Soc. 2001, 78, 525.

8. Law, N.A.; Dietzsch, W.; Duffy, N.V.; Polyhedron 2003, 22, 3423.

9. Nagano, T.; Yoshimura, T.; Chem. Rev. 2002, 102, 1235.

10. Cocco, D.; Calabrese, L.; Rigo, A.; Argese, E.; Rotillo, G.; J. Biol. Chem. 1981, 256, 8983.

11. Gringeri, A.; Keng, P.C.; Borch, R.F.; Cancer Res. 1988, 48, 5708.

12. Beer, P.D.; Berry, N.; Drew, M.G.B.; Fox, O.D.; Padilla-Tosta, M.E.; Patell, S.; Chem. Commun. 2001, 199.

13. Nami, S.A.A.; Siddiqi, K.S.; Synth. React. Inorg. Met.-Org. Chem. 2004, 34, 1581.
14. Siddiqi, K.S.; Afaq, H.; Nami, S.A.A.; Umar, A.; Synth. React. Inorg. Met.-Org. Chem. 2003, 33, 1459.

15. Reilly, C.N.; Schmid, R.W.; Sadek, F.S.; J. Chem. Edu. 1959, 36, 619 .

16. Mendham, J.; Denney, R.C.; Barnes, J.D.; Thomas, M.; Vogel, A.I.; Vogel's Textbook of Quantitative Chemical Analysis, $6^{\text {th }}$ ed., Pearson Education Ltd.: New York, 2002.

17. Geary, W.J.; Coord. Chem. Rev. 1971, 7, 81.

18. Bonati, F.; Ugo, R.; J. Organomet. Chem. 1967, 10, 257.

19. Brinkhoff, H.C.; Grotens, A.M.; Recueil Trav. Chim. Pays-Bas 1971, 90, 252.

20. Pastorek, R.; Travnicek, Z.; Kvapilova, E.; Indelar, Z.; Brezina, F.; Marek, J.; Polyhedron 1999, 18, 3401.

21. Jian, F.; Wang, Z.; Bai, Z.; You, X.; Fun, H.; Chinnakali, K.; Razak, I.A.; Polyhedron 1999, 18, 151.

22. Bensebaa, F.; Zhou, Y.; Brolo, A.G.; Irish, D.E.; Deslandes, Y.; Kruus, E.; Ellis, T.H.; Spectrochim. Acta 1999, 55A, 1229.

23. El-Sonbati, A.Z.; Synth. React. Inorg. Met.-Org. Chem. 1991, $21,203$.

24. Maroni, V.A.; Gruen, D.M.; McBeth, R.L.; Cairns, E.J.; Spectrochim. Acta 1970, 26A, 418.

25. Adams, D.M.; Churchill, R.G.; J. Chem. Soc.(A) 1970, 697.

26. Beattie, I.R.; Gilson, T.; Cocking, P.; J. Chem. Soc.(A) 1967, 702.

27. Timken, M.D.; Hendrickson, D.N.; Sinn, E.; Inorg. Chem. 1985, 24, 3947.

28. Black, J.D.; Dunsmuir, J.T.R.; Forrest, I.W.; Lane, A.P.; Inorg. Chem. 1975, 14, 1257.

29. Ziegler, R.J.; Risen, W.M.; Inorg. Chem. 1972, 11, 2796.

30. Hay, R.W.; Tarafdar, M.T.H.; J. Chem. Soc., Dalton. Trans. 1991, 823.

31. Willemese, J.; Crass Steggarda, J.A.; Keijzerss, C.P.; Struct. Bond. 1976, 28, 83.

32. Hoskins, B.F.; White, A.H.; J. Chem. Soc.(A) 1970, 1668.

33. Cotton, F. A.; Wilkinson, G.; Murillo, C.A.; Bochmann, M.; Advanced Inorganic Chemistry; $6^{\text {th }}$ ed., J. Wiley \& Sons: New York, 1999.

34. Figgis, B.N.; Introduction to Ligand Fields, Wiley Eastern Ltd.: New Delhi, 1976.

35. Kuzniarska-Biernacka, I.; Bartecki, A.; Kurzak, K.; Polyhedron 2003, 22, 997.

36. Dingle, R.; Inorg. Chem. 1968, 10, 1141.

37. Uppadin, L.H.; Weeks, J.M.; Beer, P.D.; J. Chem. Soc., Dalton Trans. 2001, 3367.

38. Bassett, J.; Denney, R.C.; Jeffrey, G.H.; Mendham, J.; Vogel's Textbook of Quantitative Inorganic Analysis; $4^{\text {th }}$ ed., Longmans: London, 1978.

39. Bajpai, A.; Tiwari, S.; Thermochim. Acta 2004, 411, 139.

40. Bell, N.A.; Johnson, E.; March, L.A.; Marsden, S.N.; Nowell, I.W.; Walker, Y.; Inorg. Chim. Acta 1989, 156, 205. 